\title{
STUDI EVALUASI DAN PENGEMBANGAN JARINGAN DISTRIBUSI AIR BERSIH PDAM KOTA MALANG PADA KECAMATAN KEDUNGKANDANG
}

\section{Evaluation and Development of Water Distribution Network PDAM Malang in Kedungkandang District}

\author{
Chairil Shaleh $^{1}$, Afrenia Dewi Angguntiana ${ }^{2}$ \\ 1,2 Jurusan Teknik Sipil, Fakultas Teknik, \\ Universitas Muhammadiyah Malang, Indonesia \\ Jl. Raya Tlogomas No. 246 Telp. (0341) 464318-128 \\ Fax. (0341) 460782 Malang 65144
}

\begin{abstract}
Clean water is a basic need for humans to get priority in the handling and fulfillment. To meet these needs should be evaluated and the development of clean water needs of the community so that optimally fulfilled. The purpose of this study is that calculates water requirements in the study area and plan the development of clean water distribution network system in the District Kedungkandang, to support the planning process pipelines are needed appropriate software tools that Waternet ver DEM09, this program serves to analyze the flow of water flowing in the pipeline and can determine the pressure in each pipe. Evaluation results show an increase in the service of PDAM Malang to the subdistrict Kedungkandang of 72\% (service in 2013) became 81.9\% (Service 2024). By using geometric regression analysis, the projected number Kedungkandang District residents in 2024 reached 194801 inhabitants. With the need for clean water that reaches the average 282.6 liters / sec, the distribution of water using gravity and pipe diameter is $25 \mathrm{~mm}-150 \mathrm{~mm}$.
\end{abstract}

Keywords: Distribution, Network, Water

\begin{abstract}
Abstrak
Air bersih merupakan kebutuhan dasar bagi manusia sehingga mendapat prioritas dalam penanganan dan pemenuhannya. Untuk memenuhi kebutuhan tersebut perlu dilakukan evaluasi dan pengembangan kebutuhan air bersih masyarakat sehingga terpenuhi secara optimal. Tujuan dari studi ini adalah yaitu menghitung kebutuhan air pada lokasi studi dan merencanakan pengembangan sistem jaringan distribusi air bersih di Kecamatan Kedungkandang, untuk mendukung proses perencanaan jaringan pipa maka dibutuhkan perangkat software yang sesuai yaitu Waternet ver DEM09, Program ini berfungsi untuk menganalisis aliran air yang mengalir di dalam pipa dan dapat mengetahui tekanan yang terjadi pada masing-masing pipa. Hasil evaluasi menunjukkan adanya peningkatan layanan air bersih PDAM Kota Malang untuk wilayah Kecamatan Kedungkandang dari 72\% ( layanan tahun 2013 ) menjadi 81,9\% ( layanan tahun 2024 ). Dengan menggunakan analisa regresi geometrik, hasil proyeksi jumlah penduduk Kecamatan Kedungkandang pada tahun 2024 mencapai 194801 jiwa. Dengan kebutuhan air bersih yang mencapai rata - rata 282,6 liter/detik, pendistribusian air menggunakan sistem gravitasi dan diameter pipa berukuran $25 \mathrm{~mm}-150 \mathrm{~mm}$.
\end{abstract}

Kata Kunci: Distribusi, Jaringan, Air Bersih

\section{PENDAHULUAN}

Kota Malang merupakan salah satu daerah otonom dan merupakan kota besar kedua di Jawa Timur setelah Kota Surabaya. Dan kota Malang merupakan salah satu penyebab tingginya tingkat kepadatan dan laju pertumbuhan penduduk, hal ini sangat berpengaruh terutama pada peningkatan kebutuhan akan pelayanan air bersih. Salah satunya adalah pada Kecamatan Kedungkandang.

Dari data terakhir yang diperoleh hingga
2013 pada wilayah Kecamatan Kedungkandang mendapatkan pemenuhan kebutuhan air dari tandon Buring dengan cakupan layanan yang terpenuhi mencapai $72 \%$ dari total keseluruhan jumlah penduduk 12 kelurahan yang mencapai 175.964 jiwa dan pelayanan dari PDAM Kota Malang untuk Kecamatan Kedungkandang dengan reservoir yang mempunyai kapasitas sebesar $3.850 \mathrm{~m} 3$.

Karena tingkat pelayanan yang kurang maksimal, sehingga perlu adanya studi evaluasi 
dan pengembangan pelayanan jaringan distribusi air bersih sampai pada akhir tahun 2024 khususnya pada Kecamatan Kedungkandang.

Dengan semakin pesatnya laju pertambahan penduduk dan meningkatnya aktifitas masyarakat, maka perlu pengembangan jaringan distribusi air bersih yang telah ada.Mengingat cakupan pelayanan hingga tahun 2013 mencapai $72 \%$ maka perlu adanya peningkatan. Sehingga perlu untuk diketahui berapa besar kebutuhan air bersih pada Kecamatan Kedungkandang hingga saat ini (tahun 2014), besar kebutuhan air bersih pada Kecamatan Kedungkandang hingga tahun 2024, serta pengembangan jaringan distribusi air bersih untuk Kecamatan Kedungkandang dengan proyeksi sampai tahun 2024.

Metode proyeksi yang digunakan adalah antara lain (Direktorat Tata Kota dan Tata Daerah, Dirjen Cipta Karya, $1987: 7$ )

\section{Metode Aritmatik}

$$
\mathrm{Pn}=\mathrm{Po}(1+\mathrm{r} . \mathrm{n})
$$

\section{Model Regresi Linier}

$$
y=a+b x
$$

$$
\text { Dimana : } \quad \begin{aligned}
\mathrm{a} & =\frac{\sum x^{2} \sum y-\sum x \sum x y}{n \sum x^{2}-\left(\sum x\right)^{2}} \\
\mathrm{~b} & =\frac{n \sum x y-\sum x \sum y}{n \sum x^{2}-\sum x^{2}}
\end{aligned}
$$

\section{Model Bunga Berganda (Metode Ge- ometrik)}

- Menghitung tingkat pertumbuhan

\begin{tabular}{|c|c|c|c|c|c|c|}
\hline \multirow{2}{*}{ no. } & \multirow{2}{*}{ Desa/ Kelurahan } & \multicolumn{5}{|c|}{ Jumlah Penduduk (jiwa) } \\
\hline & & 2009 & 2010 & 2011 & 2012 & 2013 \\
\hline 1 & Arjowinangun & 8451 & 8702 & 8954 & 9305 & 9519 \\
\hline 2 & Tlogowaru & 4402 & 4419 & 4475 & 4548 & 6090 \\
\hline 3 & Wonokoyo & 4971 & 5000 & 5076 & 5299 & 5417 \\
\hline 4 & Bumiayu & 13231 & 13526 & 13890 & 14413 & 14904 \\
\hline 5 & Buring & 8289 & 8493 & 8614 & 8970 & 9282 \\
\hline 6 & Mergosono & 17019 & 17625 & 17715 & 17861 & 17781 \\
\hline 7 & Kotalama & 29655 & 29431 & 29062 & 28865 & 28888 \\
\hline 8 & Kedungkandang & 9204 & 9686 & 9689 & 9836 & 9972 \\
\hline 9 & Lesanpuro & 18119 & 18067 & 18100 & 18208 & 17462 \\
\hline 10 & Madyopuro & 17169 & 17243 & 17126 & 16944 & 16692 \\
\hline 11 & Cemorokandang & 8467 & 8801 & 9149 & 9559 & 10023 \\
\hline \multirow[t]{2}{*}{12} & Sawojajar & 29702 & 29651 & 29681 & 29754 & 29934 \\
\hline & jumlah & 168679 & 170644 & 171531 & 173562 & 175964 \\
\hline
\end{tabular}
pemakai.

$$
r=\frac{P_{n+1}-P_{n}}{P_{n}}
$$

Tabel 1. Data Penduduk

Sumber : BPS Kota Malang
- Memperkirakan jumlah pemakai pada tahun akhir rencana

$$
\mathrm{Pn}=\text { Po } .(1+r)^{\mathrm{n}}
$$

\section{Metode Eksponensial}

Dimana :

$$
\mathrm{Pn}=\mathrm{Po} \cdot \mathrm{e}^{(\mathrm{r} . \mathrm{n})}
$$

$\mathrm{Pn}=$ Perkiraan jumlah pemakai pada tahun akhir perencanaan.

Po $=$ Jumlah pemakai pada tahun akhir (data).

$\mathrm{Pn}+1=$ Jumlah pemakai pada tahun ke $-\mathrm{n}+1$ (data).

$\mathrm{n}$ = Periode waktu yang digunakan.

$\mathrm{a}=$ Tingkat pertumbuhan (diambil dari hasil perhitungan diatas).

$r$ = Rata-rata pertumbuhan pemakai tiap tahun.

e = Bilangan pokok dari sistem logaritma natural $(2,7182818)$

$\mathrm{a} \& \mathrm{~b}=$ variabel

\section{METODE PENELITIAN}

Setelah mengetahui lokasi daerah studi, maka dilakukan pengumpulan data yang diperlukan dalam melakukan studi. Data - data yang diperlukan antara lain :

- Data Penduduk yang dievaluasi

- Data Topografi dan Sarana Penyediaan Air Bersih Existing

- Data Pelayanan PDAM Kota Malang pada Kecamatan Kedungkandang pada Akhir Tahun 2013 


\section{Tahapan studi}

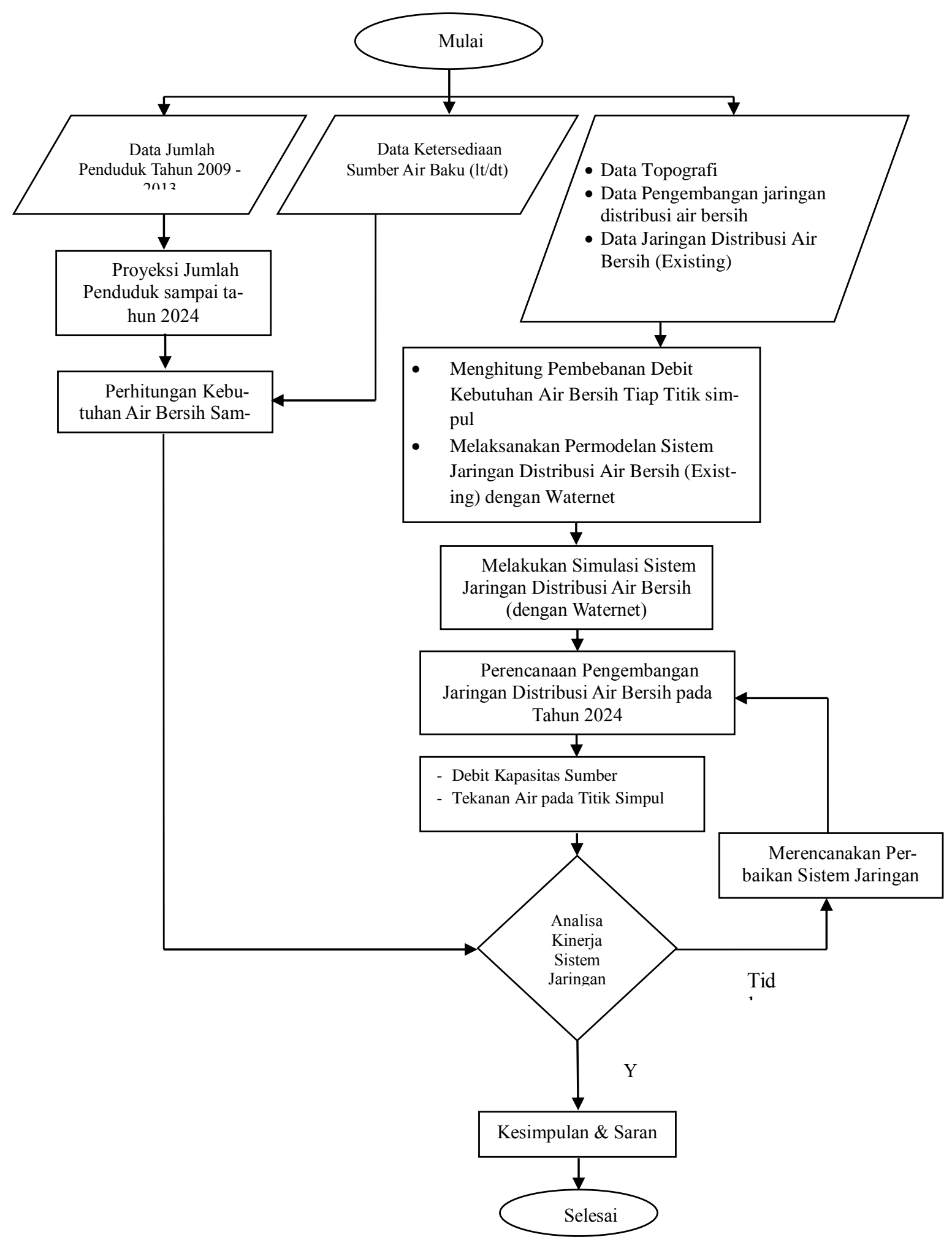

Gambar 1. Tahapan Studi 


\section{HASIL DAN PEMBAHASAN}

\section{Hasil Perhitungan}

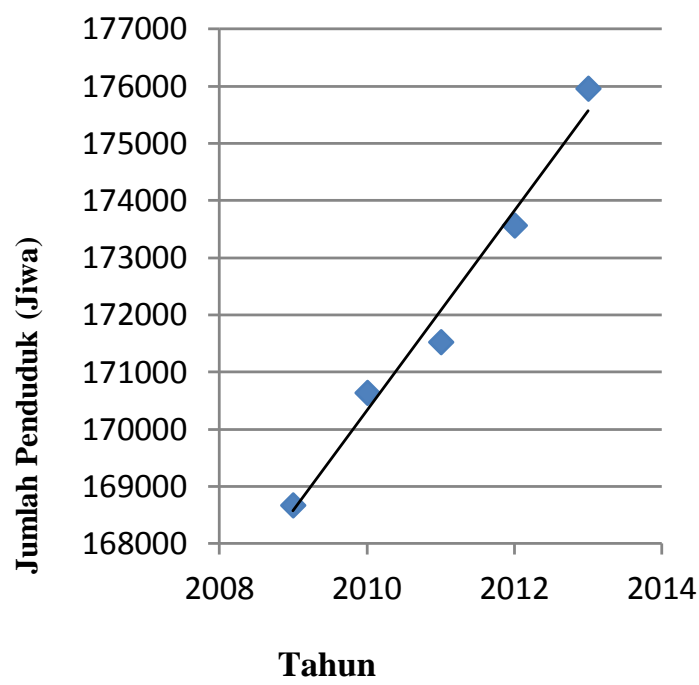

Gambar 2. Grafik Data Pertumbuhan Penduduk

Sumber : BPS Kota Malang
Tabel 2. Pertumbuhan Penduduk Metode Aritmatik

\begin{tabular}{cccc}
\hline No & Tahun & $\begin{array}{c}\text { Jml } \\
\text { Penduduk } \\
\text { (jiwa })\end{array}$ & $\begin{array}{c}\text { Hasil } \\
\text { Perhitungan }\end{array}$ \\
\hline 1 & 2009 & 168679 & 171056 \\
2 & 2010 & 170644 & 173434 \\
3 & 2011 & 171531 & 175811 \\
4 & 2012 & 173562 & 178188 \\
5 & 2013 & 175964 & 180566 \\
\hline \multicolumn{4}{c}{ Sumber $:$ BPS Kota Malang }
\end{tabular}

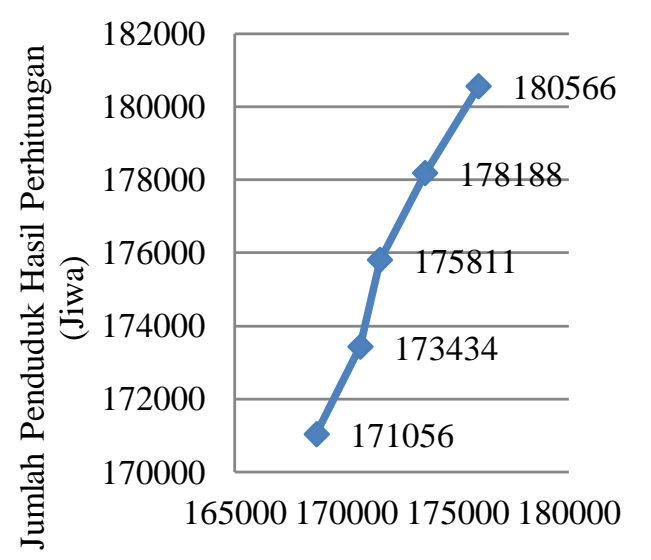

Jumlah Penduduk Sesungguhnya (Jiwa)

Gambar 3. Grafik Data Pertumbuhan Penduduk (Aritmatik)

Tabel 3. Pertumbuhan Penduduk Metode Linier

\begin{tabular}{|c|c|c|c|c|c|c|c|}
\hline $\begin{array}{l}\text { No } \\
\text { (X) }\end{array}$ & Tahun & $\begin{array}{l}\text { Jml Penduduk } \\
\text { ( jiwa ) } \\
\text { (Y) }\end{array}$ & $\begin{array}{l}\text { Hasil Perhi- } \\
\text { tungan } \\
\text { Yi }\end{array}$ & $\mathrm{X}^{\wedge} 2$ & $\mathrm{XY}$ & (Yi-Yrata2) & $(Y i-Y r a t a 2)^{\wedge} 2$ \\
\hline 1 & 2009 & 168679 & 168578 & 1 & 168679 & -3498 & 12233206 \\
\hline 2 & 2010 & 170644 & 170327 & 4 & 341288 & -1749 & 3058301 \\
\hline 3 & 2011 & 171531 & 172076 & 9 & 514593 & 0 & 0 \\
\hline 4 & 2012 & 173562 & 173825 & 16 & 694248 & 1749 & 3058301 \\
\hline 5 & 2013 & 175964 & 175574 & 25 & 879820 & 3498 & 12233206 \\
\hline 15 & Jumlah & 860380 & 860380 & 55 & 2598628 & 0 & 30583014 \\
\hline \multicolumn{2}{|c|}{ Rata - rata } & 172076 & 172076 & 11 & 519726 & 0 & 6116603 \\
\hline
\end{tabular}

Sumber : Hasil Perhitungan 


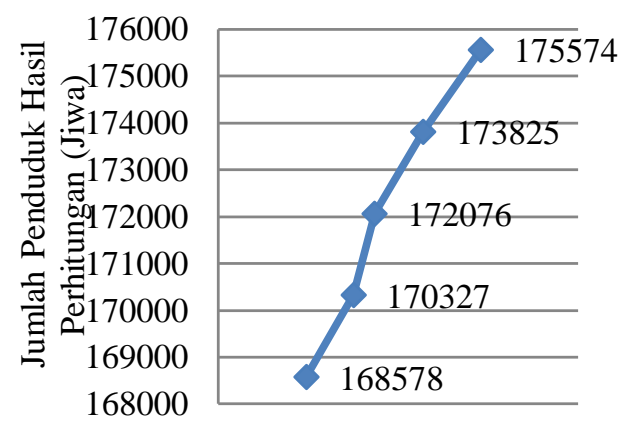

165000170000175000180000

Jumlah Penduduk Sesungguhnya (Jiwa)

Gambar 4. Grafik Data Pertumbuhan Penduduk (Regresi Linier)

Tabel 4. Pertumbuhan Penduduk Metode Geometrik

\begin{tabular}{cccc}
\hline No & Tahun & $\begin{array}{c}\text { Jml Penduduk } \\
\text { ( jiwa ) }\end{array}$ & $\begin{array}{c}\text { Hasil } \\
\text { Perhitungan }\end{array}$ \\
\hline 1 & 2009 & 168679 & 171056 \\
2 & 2010 & 170644 & 173467 \\
3 & 2011 & 171531 & 175912 \\
4 & 2012 & 173562 & 178391 \\
5 & 2013 & 175964 & 180906 \\
\hline
\end{tabular}

Sumber : Hasil perhitungan

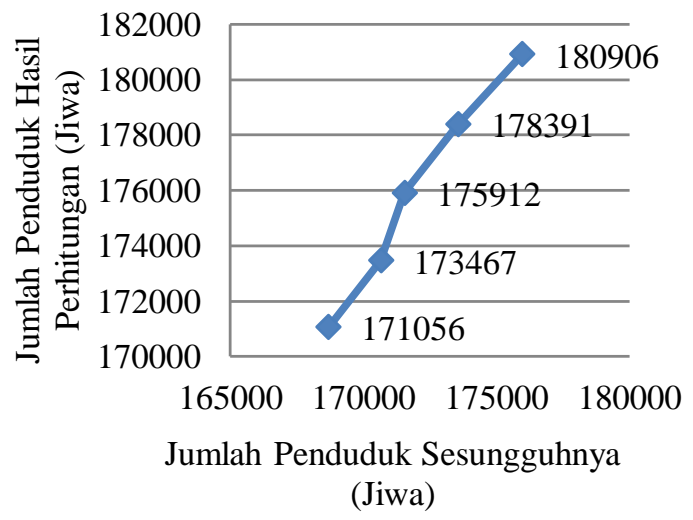

Gambar 5. Grafik Data Pertumbuhan Penduduk (Geometrik)
Tabel 5. Pertumbuhan Penduduk Metode Eksponensial

\begin{tabular}{cccc}
\hline No & Tahun & $\begin{array}{c}\text { Jml } \\
\text { Penduduk } \\
\text { (jiwa })\end{array}$ & $\begin{array}{c}\text { Hasil } \\
\text { Perhitungan }\end{array}$ \\
\hline 1 & 2009 & 168679 & 171073 \\
2 & 2010 & 170644 & 173501 \\
3 & 2011 & 171531 & 175964 \\
4 & 2012 & 173562 & 178462 \\
5 & 2013 & 175964 & 180995 \\
\hline \multicolumn{4}{c}{ Sumber : Hasil perhitungan }
\end{tabular}

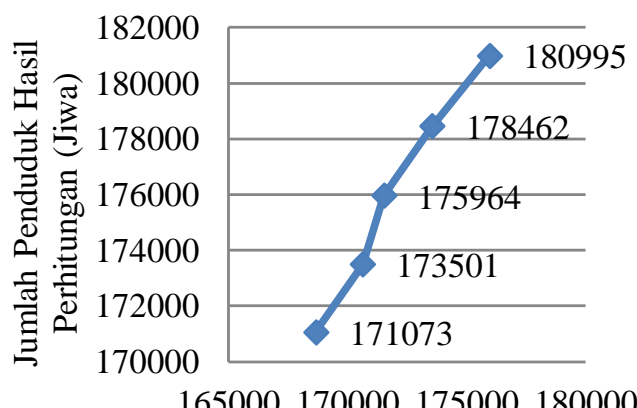

Jumlah Penduduk Sesungguhnya (Jiwa)

Gambar 6. Grafik Data Pertumbuhan Penduduk (Eksponensial)

Tabel 6. Perbandingan Proyeksi Pertumbuhan Penduduk Metode Aritmatik, Metode Regresi Linier, Metode geometrik, dan Metode Eksponensial

\begin{tabular}{ccccccc}
\hline No. & Tahun & $\begin{array}{c}\text { Jml Penduduk } \\
\text { (jiwa })\end{array}$ & ARITMATIK & GEOMETRIK & EKSPONENSIAL & $\begin{array}{c}\text { REGRESI } \\
\text { LINIER }\end{array}$ \\
\hline 1 & 2009 & 168679 & 171056 & 171056 & 171073 & 168578 \\
2 & 2010 & 170644 & 173434 & 173467 & 173501 & 170327 \\
3 & 2011 & 171531 & 175811 & 175912 & 175964 & 172076 \\
4 & 2012 & 173562 & 178188 & 178391 & 178462 & 173825 \\
5 & 2013 & 175964 & 180566 & 180906 & 180995 & 175574 \\
\hline
\end{tabular}

Sumber : Hasil Perhitungan 

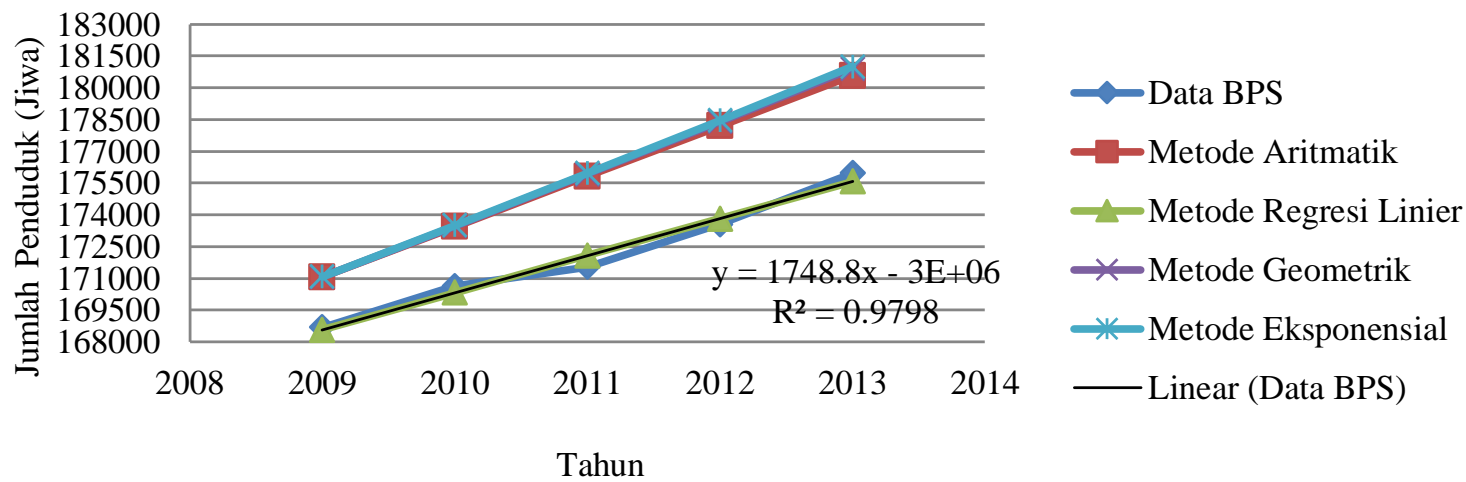

Gambar 7. Grafik Perbandingan Proyeksi

Tabel 7. Perhitungan Proyeksi Penduduk Tahun 2014-2018

\begin{tabular}{|c|c|c|c|c|c|c|c|c|c|c|c|c|}
\hline \multirow{2}{*}{ no. } & \multirow{2}{*}{$\begin{array}{l}\text { Desa/ Ke- } \\
\text { lurahan }\end{array}$} & \multicolumn{11}{|c|}{ Jumlah Penduduk (jiwa) } \\
\hline & & 2014 & 2015 & 2016 & 2017 & 2018 & 2019 & 2020 & 2021 & 2022 & 2023 & 2024 \\
\hline 1 & Arjowinangun & 9808 & 10082 & 10356 & 10630 & 10904 & 11177 & 11451 & 11725 & 11999 & 12273 & 12547 \\
\hline 2 & Tlogowaru & 5838 & 6189 & 6539 & 6890 & 7240 & 7591 & 7941 & 8292 & 8642 & 8993 & 9343 \\
\hline 3 & Wonokoyo & 5510 & 5629 & 5748 & 5867 & 5986 & 6105 & 6225 & 6344 & 6463 & 6582 & 6701 \\
\hline 4 & Bumiayu & 15263 & 15686 & 16109 & 16533 & 16956 & 17379 & 17803 & 18226 & 18649 & 19072 & 19496 \\
\hline 5 & Buring & 9469 & 9715 & 9961 & 10207 & 10454 & 10700 & 10946 & 11193 & 11439 & 11685 & 11932 \\
\hline 6 & Mergosono & 18128 & 18304 & 18480 & 18656 & 18832 & 19008 & 19184 & 19360 & 19536 & 19712 & 19888 \\
\hline 7 & Kotalama & 28550 & 28340 & 28130 & 27920 & 27710 & 27500 & 27290 & 27080 & 26870 & 26660 & 26450 \\
\hline 8 & Kedungkandang & 10183 & 10352 & 10520 & 10689 & 10858 & 11026 & 11195 & 11363 & 11532 & 11701 & 11869 \\
\hline 9 & Lesanpuro & 17639 & 17522 & 17405 & 17287 & 17170 & 17053 & 16936 & 16818 & 16701 & 16584 & 16466 \\
\hline 10 & Madyopuro & 16659 & 16534 & 16408 & 16283 & 16158 & 16032 & 15907 & 15782 & 15657 & 15531 & 15406 \\
\hline 11 & Cemorokandang & 10361 & 10748 & 11135 & 11522 & 11909 & 12296 & 12683 & 13070 & 13457 & 13844 & 14231 \\
\hline \multirow[t]{2}{*}{12} & Sawojajar & 29915 & 29971 & 30028 & 30085 & 30141 & 30198 & 30255 & 30311 & 30368 & 30425 & 30482 \\
\hline & jumlah & 177322 & 179071 & 180820 & 182569 & 184318 & 186066 & 187815 & 189564 & 191313 & 193062 & 194810 \\
\hline
\end{tabular}

Sumber : Hasil Perhitungan

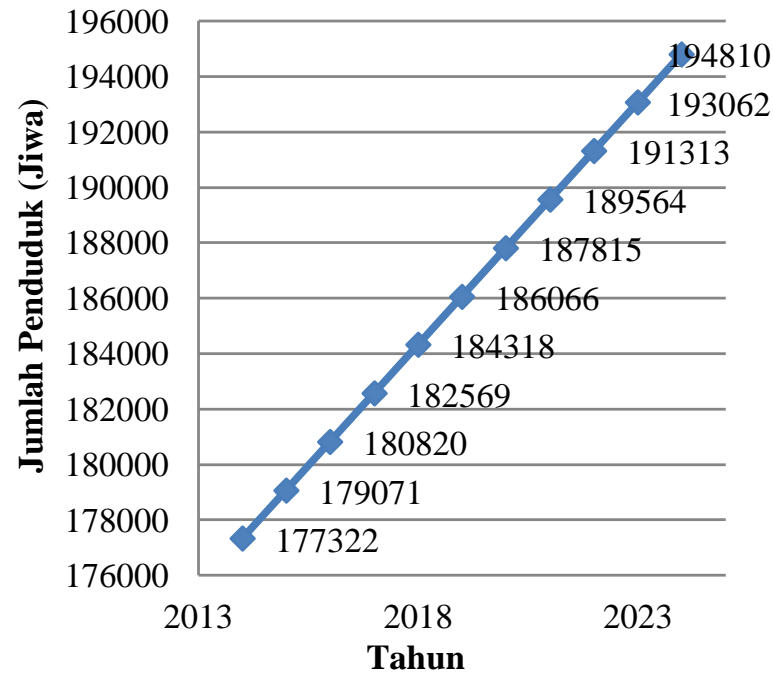

Gambar 8. Grafik pertumbuhan penduduk tahun proyeksi 2024
Tabel 8. Perkembangan layanan PDAM tahun $2014-2024$

\begin{tabular}{ccc}
\hline No. & Tahun & $\begin{array}{c}\text { Presentase } \\
\text { Pelayanan }\end{array}$ \\
\hline 1 & 2014 & $72.90 \%$ \\
2 & 2015 & $73.80 \%$ \\
3 & 2016 & $74.70 \%$ \\
4 & 2017 & $75.60 \%$ \\
5 & 2018 & $76.50 \%$ \\
6 & 2019 & $77.40 \%$ \\
7 & 2020 & $78.30 \%$ \\
8 & 2021 & $79.20 \%$ \\
9 & 2022 & $80.10 \%$ \\
10 & 2023 & $81.00 \%$ \\
11 & 2024 & $81.90 \%$ \\
\hline \multicolumn{3}{l}{ Sumber : Hasil Perhitungan }
\end{tabular}


Tabel 9. Proyeksi kebutuhan Air Bersih

\begin{tabular}{|c|c|c|c|c|c|c|c|c|}
\hline \multirow{2}{*}{ No. } & \multirow{2}{*}{ Uraian } & \multirow{2}{*}{ Satuan } & \multicolumn{6}{|c|}{ Tahun } \\
\hline & & & 2013 & 2014 & 2015 & 2016 & 2017 & 2018 \\
\hline A & ASUMSI PERHITUNGAN & & & & & & & \\
\hline \multirow[t]{3}{*}{1} & Penduduk yang dilayani & & & & & & & \\
\hline & a. Sambungan Rumah Tangga & Jiwa & 5 & 5 & 5 & 5 & 5 & 5 \\
\hline & b. Sambungan Hidran Umum & Jiwa & 100 & 100 & 100 & 100 & 100 & 100 \\
\hline \multirow[t]{3}{*}{2} & Faktor Pemakaian Air & & & & & & & \\
\hline & a. Harian maksimum & & 1 & 1 & 1 & 1 & 1 & 1 \\
\hline & b. Jam puncak & & 2 & 2 & 2 & 2 & 2 & 2 \\
\hline \multirow[t]{2}{*}{3} & Kebutuhan Non Domestik & & & & & & & \\
\hline & Prosentase dari domestik & $\%$ & 15 & 15 & 15 & 15 & 15 & 15 \\
\hline \multirow[t]{2}{*}{4} & Kehilangan Air & & & & & & & \\
\hline & Prosentase dari total kebutuhan & $\%$ & 30 & 30 & 30 & 30 & 30 & 30 \\
\hline $\mathrm{B}$ & $\begin{array}{l}\text { PERHITUNGAN KEBUTUHAN } \\
\text { AIR }\end{array}$ & & & & & & & \\
\hline 1 & Jumlah Penduduk & Jiwa & 175574 & 177322 & 179071 & 180820 & 182569 & 184318 \\
\hline 2 & Prosentase penduduk yang dilayani & $\%$ & 72.00 & 72.90 & 73.80 & 74.70 & 75.60 & 76.50 \\
\hline 3 & Jumlah penduduk yang dilayani & Jiwa & 126413 & 129268 & 132155 & 135073 & 138022 & 141003 \\
\hline \multirow[t]{14}{*}{4} & Kebutuhan Air Domestik & & & & & & & \\
\hline & I. Sambungan Rumah Tangga & & & & & & & \\
\hline & a. Pemakaian air domestik & $\begin{array}{l}\text { lt } / \mathrm{hr} \\
/ \text { jiwa }\end{array}$ & 150 & 150 & 150 & 150 & 150 & 150 \\
\hline & b. Prosentase Pelayanan & $\%$ & 80 & 80 & 80 & 80 & 85 & 85 \\
\hline & c. Jumlah penduduk yang dilayani & Jiwa & 101130 & 103414 & 105724 & 108058 & 117319 & 119853 \\
\hline & d. Jumlah sambungan & Unit & 20226 & 20683 & 21145 & 21612 & 23464 & 23971 \\
\hline & e. Kebutuhan Air & $\mathrm{m}^{3} / \mathrm{hr}$ & 15170 & 15512 & 15859 & 16209 & 17598 & 17978 \\
\hline & II. Sambungan Hidran Umum & & & & & & & \\
\hline & a. Pemakaian air & $\begin{array}{l}\text { lt } / \mathrm{hr} \\
/ \text { jiwa }\end{array}$ & 30 & 30 & 30 & 30 & 30 & 30 \\
\hline & b. Prosentase Pelayanan & $\%$ & 2 & 2 & 2 & 2 & 2 & 2 \\
\hline & c. Jumlah penduduk yang dilayani & Jiwa & 2528 & 2585 & 2643 & 2701 & 2760 & 2115 \\
\hline & d. Jumlah sambungan & Unit & 25 & 26 & 26 & 27 & 28 & 21 \\
\hline & e. Kebutuhan Air & $\mathrm{m}^{3} / \mathrm{hr}$ & 75.85 & 77.56 & 79.29 & 81.04 & 82.81 & 63.45 \\
\hline & III. Total Kebutuhan Air Domestik & & & & & & & \\
\hline 5 & Kebutuhan Non Domestik & $\mathrm{m}^{3} / \mathrm{hr}$ & 2287 & 2338 & 2391 & 2443 & 2652 & 2706 \\
\hline 6 & Total Kebutuhan Air & $\mathrm{m}^{3} / \mathrm{hr}$ & 17532 & 17928 & 18329 & 18733 & 20333 & 20748 \\
\hline 7 & Kehilangan Air & $\mathrm{m}^{3} / \mathrm{hr}$ & 5260 & 5378 & 5499 & 5620 & 6100 & 6224 \\
\hline \multirow[t]{3}{*}{8} & Kebutuhan Air Rata-rata & $\mathrm{m}^{3} / \mathrm{hr}$ & 22792 & 23307 & 23827 & 24353 & 26433 & 26972 \\
\hline & & $\mathrm{m}^{3} / \mathrm{jam}$ & 949.7 & 971.1 & 992.8 & 1014.7 & 1101.4 & 1123.8 \\
\hline & & $1 \mathrm{t} / \mathrm{dt}$ & 263.8 & 269.8 & 275.8 & 281.9 & 305.9 & 312.2 \\
\hline \multirow[t]{2}{*}{9} & Kebutuhan Air Harian Maksimum & $\mathrm{m}^{3} / \mathrm{hr}$ & 26211 & 26803 & 27401 & 28006 & 30397 & 31018 \\
\hline & & $\mathrm{lt} / \mathrm{dt}$ & 303.4 & 310.2 & 317.1 & 324.1 & 351.8 & 359.0 \\
\hline \multirow[t]{2}{*}{10} & Kebutuhan Jam Puncak & $\mathrm{m}^{3} / \mathrm{hr}$ & 34188 & 34960 & 35741 & 36530 & 39649 & 40458 \\
\hline & & $1 \mathrm{t} / \mathrm{dt}$ & 395.7 & 404.6 & 413.7 & 422.8 & 458.9 & 468.3 \\
\hline
\end{tabular}

Sumber : Hasil Perhitungan 
Lanjuan Tabel 9. Proyeksi kebutuhan Air Bersih

\begin{tabular}{|c|c|c|c|c|c|c|c|c|}
\hline \multirow{2}{*}{ No. } & \multirow{2}{*}{ Uraian } & \multirow{2}{*}{ Satuan } & \multicolumn{6}{|c|}{ Tahun } \\
\hline & & & 2019 & 2020 & 2021 & 2022 & 2023 & 2024 \\
\hline A & ASUMSI PERHITUNGAN & & & & & & & \\
\hline \multirow[t]{3}{*}{1} & Penduduk yang dilayani & & & & & & & \\
\hline & a. Sambungan Rumah Tangga & Jiwa & 5 & 5 & 5 & 5 & 5 & 5 \\
\hline & b. Sambungan Hidran Umum & Jiwa & 100 & 100 & 100 & 100 & 100 & 100 \\
\hline \multirow[t]{3}{*}{2} & Faktor Pemakaian Air & & & & & & & \\
\hline & a. Harian maksimum & & 1 & 1 & 1 & 1 & 1 & 1 \\
\hline & b. Jam puncak & & 2 & 2 & 2 & 2 & 2 & 2 \\
\hline \multirow[t]{2}{*}{3} & Kebutuhan Non Domestik & & & & & & & \\
\hline & Prosentase dari domestik & $\%$ & 15 & 15 & 15 & 15 & 15 & 15 \\
\hline \multirow[t]{2}{*}{4} & Kehilangan Air & & & & & & & \\
\hline & Prosentase dari total kebutuhan & $\%$ & 30 & 30 & 30 & 30 & 30 & 30 \\
\hline $\mathrm{B}$ & $\begin{array}{l}\text { PERHITUNGAN KEBUTUHAN } \\
\text { AIR }\end{array}$ & & & & & & & \\
\hline 1 & Jumlah Penduduk & Jiwa & 186066 & 187815 & 189564 & 191313 & 193062 & 194810 \\
\hline 2 & Prosentase penduduk yang dilayani & $\%$ & 77.40 & 78.30 & 79.20 & 80.10 & 81.00 & 81.90 \\
\hline 3 & Jumlah penduduk yang dilayani & Jiwa & 144015 & 147059 & 150135 & 153242 & 156380 & 159550 \\
\hline \multirow[t]{14}{*}{4} & Kebutuhan Air Domestik & & & & & & & \\
\hline & I. Sambungan Rumah Tangga & & & & & & & \\
\hline & a. Pemakaian air domestik & $\begin{array}{l}\text { lt } / \mathrm{hr} \\
/ \text { jiwa }\end{array}$ & 150 & 150 & 150 & 150 & 150 & 150 \\
\hline & b. Prosentase Pelayanan & $\%$ & 85 & 85 & 95 & 95 & 95 & 95 \\
\hline & c. Jumlah penduduk yang dilayani & Jiwa & 122413 & 125000 & 142628 & 145579 & 148561 & 151572 \\
\hline & d. Jumlah sambungan & Unit & 24483 & 25000 & 28526 & 29116 & 29712 & 30314 \\
\hline & e. Kebutuhan Air & $\mathrm{m}^{3} / \mathrm{hr}$ & 18362 & 18750 & 21394 & 21837 & 22284 & 22736 \\
\hline & II. Sambungan Hidran Umum & & & & & & & \\
\hline & a. Pemakaian air & $\begin{array}{l}\text { lt } / \mathrm{hr} \\
\text { /jiwa }\end{array}$ & 30 & 30 & 30 & 30 & 30 & 30 \\
\hline & b. Prosentase Pelayanan & $\%$ & 2 & 2 & 2 & 1 & 1 & 1 \\
\hline & c. Jumlah penduduk yang dilayani & Jiwa & 2160 & 2206 & 2252 & 1532 & 1564 & 1595 \\
\hline & d. Jumlah sambungan & Unit & 22 & 22 & 23 & 15 & 16 & 16 \\
\hline & e. Kebutuhan Air & $\mathrm{m}^{3} / \mathrm{hr}$ & 64.81 & 66.18 & 67.56 & 45.97 & 46.91 & 47.86 \\
\hline & III. Total Kebutuhan Air Domestik & & & & & & & \\
\hline 5 & Kebutuhan Non Domestik & $\mathrm{m}^{3} / \mathrm{hr}$ & 2764 & 2822 & 3219 & 3282 & 3350 & 3418 \\
\hline 6 & Total Kebutuhan Air & $\mathrm{m}^{3} / \mathrm{hr}$ & 21191 & 21639 & 24681 & 25165 & 25681 & 26201 \\
\hline 7 & Kehilangan Air & $\mathrm{m}^{3} / \mathrm{hr}$ & 6357 & 6492 & 7404 & 7550 & 7704 & 7860 \\
\hline \multirow[t]{3}{*}{8} & Kebutuhan Air Rata-rata & $\mathrm{m}^{3} / \mathrm{hr}$ & 27548 & 28130 & 32085 & 32715 & 33385 & 34062 \\
\hline & & $\mathrm{m}^{3} / \mathrm{jam}$ & 1147.8 & 1172.1 & 1336.9 & 1363.1 & 1391.0 & 1419.2 \\
\hline & & $\mathrm{lt} / \mathrm{dt}$ & 318.8 & 325.6 & 371.4 & 378.6 & 386.4 & 394.2 \\
\hline \multirow[t]{2}{*}{9} & Kebutuhan Air Harian Maksimum & $\mathrm{m}^{3} / \mathrm{hr}$ & 31680 & 32350 & 36898 & 37622 & 38393 & 39171 \\
\hline & & lt $/ \mathrm{dt}$ & 366.7 & 374.4 & 427.1 & 435.4 & 444.4 & 453.4 \\
\hline \multirow[t]{2}{*}{10} & Kebutuhan Jam Puncak & $\mathrm{m}^{3} / \mathrm{hr}$ & 41322 & 42195 & 48128 & 49072 & 50077 & 51092 \\
\hline & & $1 \mathrm{t} / \mathrm{dt}$ & 478.3 & 488.4 & 557.0 & 568.0 & 579.6 & 591.3 \\
\hline
\end{tabular}

Sumber : Hasil Perhitungan 


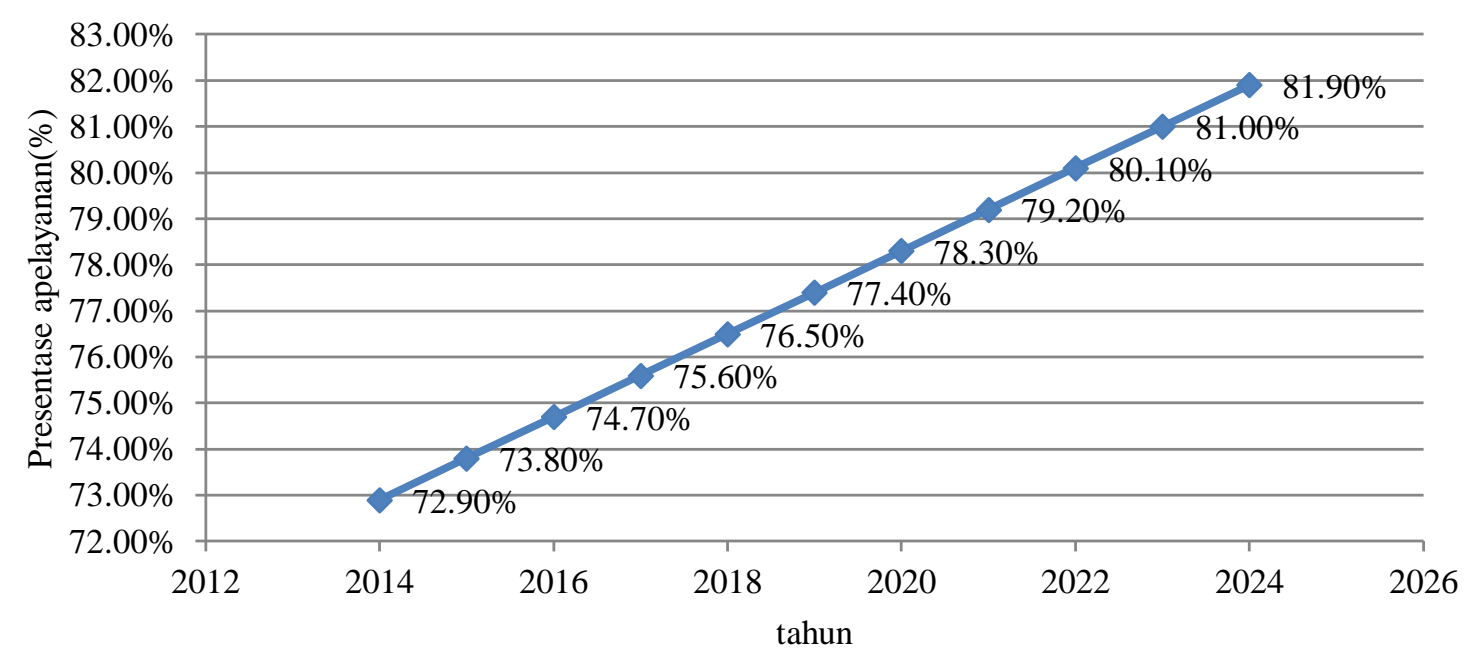

Gambar 9. Grafik Perkembangan Pelayanan PDAM Tahun 2014-2024

\section{Perhitungan Fluktuasi Pemakaian Air}

Tabel 10. Keseimbangan Air untuk Kecamatan Kedungkandang dalam 24 jam

\begin{tabular}{cccc}
\hline Jam ke & $\begin{array}{c}\text { Kedalaman } \\
(\mathrm{m})\end{array}$ & Elevasi muka air & Status Tangki \\
\hline 1 & 2.73 & 486.73 & Diisi \\
2 & 3.45 & 487.45 & Diisi \\
3 & 4.18 & 488.18 & Diisi \\
4 & 4.3 & 488.3 & Diisi \\
5 & 4.43 & 488.43 & Diisi \\
6 & 4.56 & 488.56 & Diisi \\
7 & 4.68 & 488.68 & Diisi \\
8 & 4.8 & 488.8 & Diisi \\
9 & 4.93 & 488.93 & Diisi \\
10 & 4.86 & 488.86 & Dikuras \\
11 & 4.78 & 488.78 & Dikuras \\
12 & 4.71 & 488.71 & Dikuras \\
13 & 4.64 & 488.64 & Dikuras \\
14 & 4.57 & 488.57 & Dikuras \\
15 & 4.5 & 488.5 & Dikuras \\
16 & 3.83 & 487.83 & Dikuras \\
17 & 3.17 & 487.17 & Dikuras \\
18 & 2.5 & 486.5 & Dikuras \\
19 & 2.62 & 486.62 & Diisi \\
20 & 2.74 & 486.74 & Diisi \\
21 & 2.87 & 486.87 & Diisi \\
22 & 3.59 & 487.59 & Diisi \\
23 & 4.31 & 488.31 & Diisi \\
24 & 5. & 489. & Diisi \\
\hline
\end{tabular}

Sumber : Hasil Perhitungan 


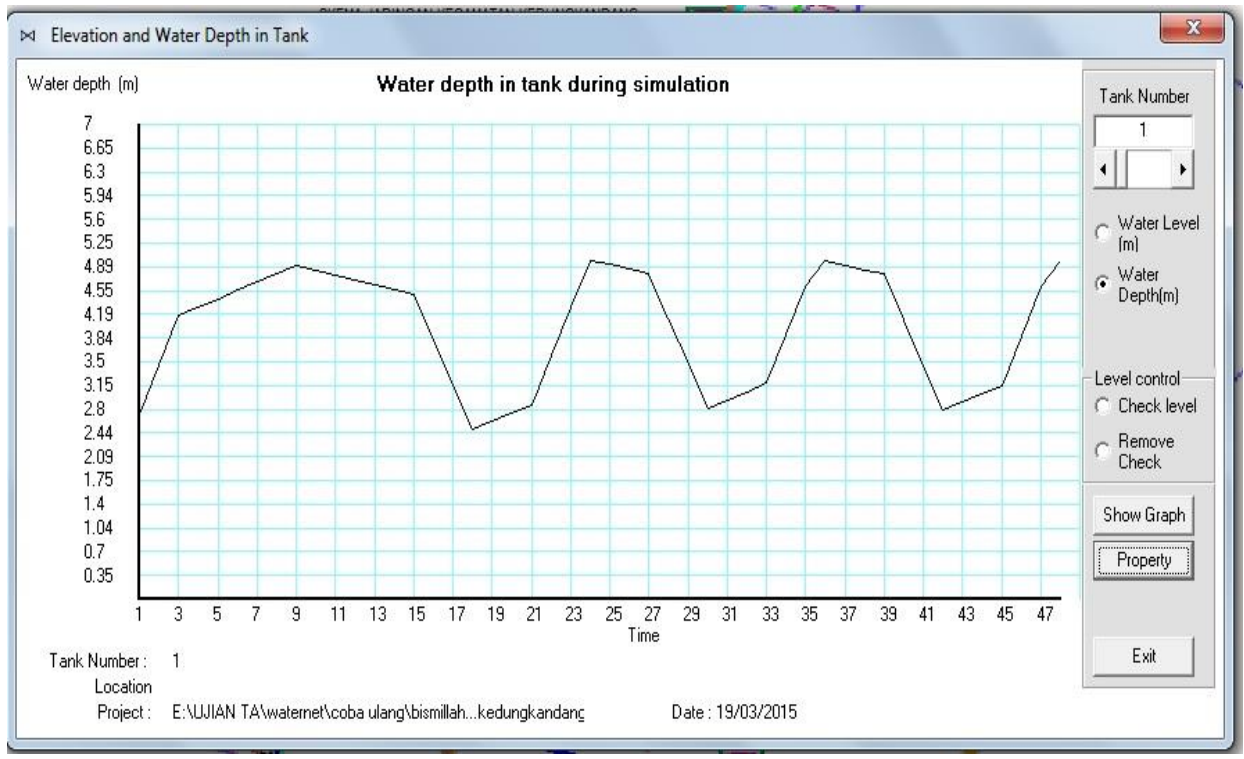

Gambar 10. Grafik Fluktuasi Kebutuhan Air untuk Reservoir Kecamatan Kedungkandang dalam 24 jam

Dari perhitungan fluktuasi pemakaian air, maka dapat diketahui volume reservoir yang di perlukan adalah sebesar $3100 \mathrm{~m}^{3}$.

\section{Hasil Pengembangan Menggunakan Pro- gram Waternet}

- Sisa tekanan maksimum untuk seluruh node selama simulasi $=13,72$

- Sisa tekanan minimum untuk seluruh node selama simulasi $=3,26$

- Fluktuasi muka air sebesar $85 \%$

Sumber : Hasil running Program Waternet

\section{KESIMPULAN DAN SARAN}

\section{Kesimpulan}

Dengan analisa dan perhitungan yang telah dilakukan dapat disimpulkan bahwa :

- Kebutuhan air bersih pada tahun 2013 di daerah studi adalah sebesar 263,8 lt/dt, sumber yang digunakan : sumber mata air Wendit yang digunakan untuk daerah layanan sebesar $376 \mathrm{lt} / \mathrm{dt}$ dengan kapasitas tampungan reservoir tandon Buring sebesar $3.850 \mathrm{~m}^{3}$, tingkat layanan PDAM Kota Malang sebesar $72 \%$. Untuk Kebutuhan air bersih saat ini ( akhir 2014 ) adalah sebesar 269,8 liter/detik dengan tingkat layanan sebesar $72,9 \%$.
- Kebutuhan air bersih pada sampai dengan tahun akhir rencana ( tahun 2024 ) di daerah studi adalah sebesar 394,2 liter/detik dari sumber mata air Wendit yang dibutuhkan, dengan jumlah penduduk 194.810 jiwa. kebutuhan air adalah 150 liter/orang/hari dan tingkat layanan optimal PDAM mencapai $81,9 \%$.

- Dengan menggunakan data topografi dan jaringan distribusi yang lama maka dapat dievaluasi dan dikembangkan jaringan distribusi air minum tersebut, dengan menggunakan program Waternet, maka dihasilkan 84 node dan 86 jalur pipa utama yang melayani daerah layanan yang meliputi 12 Kelurahan dan sumber yang digunakan adalah dari mata air Sumber Wendit dengan Reservoir Buring.

\section{Saran}

Dalam analisa dan perhitungan yang dilakukan ini diharapkan dapat dikembangkan lebih lanjut untuk pendistribusian pada wilayah layanan, agar tercapai sasaran pemenuhan kebutuhan air bersih di Kecamatan Kedungkandang pada umumnya dan bagi instansi pemerintah dalam hal ini PDAM pada khususnya. Dimana perhitungan ini adalah salah satu alternatif perencanaan distribusi air bersih di daerah layanan PDAM Kota Malang pada Kecamatan Kedungkandang agar dapat dihasilkan perencanaan yang optimal dan 
efisien biaya sehingga didapat nilai ekonomis yang tinggi.

\section{DAFTAR PUSTAKA}

Triatmodjo Bambang. 1995. Hidraulika I. Yogyakarta : Beta Offset.

Triatmodjo Bambang. 2008. Hidraulika II. Yogyakarta : Beta Offset.

Supirin. 2002. Pelestarian Sumber Daya Tanah dan Air. Yogyakarta : Andi.

Susongko Djoko, Franzini Joseph. B, Linskey Ray. K. 1991. Teknik Sumber daya Air, Jakarta : Erlangga.

Kodoatie Robert. J. 2002, Hidrolika Terapan Aliran pada Saluran Terbuka dan Pipa. Yogyakarta : Andi.

Laboratorium Teknik Sipil, Pedoman Praktikum Waternet. 